\title{
Erratum to: A new two-dimensional analytical subthreshold behavior model for submicron Triple Material Gate (TM) GaN MESFET
}

\author{
N. Lakhdar
}

Published online: 6 August 2014

(C) Springer Science+Business Media New York 2014

\section{Erratum to: J Comput Electron}

DOI 10.1007/s10825-014-0591-y

According to Prof. Faycal Djeffal, he is not a co-author of this paper. On his request, his authorship is withdrawn via this erratum. He had no contribution to the writing process of this paper. The authorship of this paper is attributed only to Dr. Nacereddine Lakhdar.

The online version of the original article can be found under doi:10.1007/s10825-014-0591-y.

N. Lakhdar $(\varangle)$

LEA, Department of Electronics, University of Batna,

05000 Batna, Algeria

e-mail: nacereddine_1@hotmail.fr

N. Lakhdar

Department of Electronics, University of El Oued,

39000 El Oued, Algeria 